\title{
Evaluation of Working Temperature in Wind Turbine Bearings by Simulation of Lubricant Level
}

\author{
Yorley Arbella Feliciano ${ }^{1}$, Carlos A. Trinchet Varela ${ }^{2}$, Javier A. Vargas Guativas ${ }^{3}$, Leandro L. Lorente-Leyva ${ }^{4 *}$, \\ Diego H. Peluffo-Ordóñez ${ }^{4,5}$ \\ ${ }^{1}$ Departamento Ingeniería Mecánica, Universidad de Holguín, Holguín 80100, Cuba \\ ${ }^{2}$ Centro de Estudios CAD/CAM, Universidad de Holguín, Holguín 80100, Cuba \\ ${ }^{3}$ Facultad de Ciencias Básicas e Ingeniería, Universidad de los Llanos, Villavicencio 1745, Colombia \\ ${ }^{4}$ SDAS Research Group, Ibarra 100150, Ecuador \\ ${ }^{5}$ Ingeniería Informática, Corporación Universitaria Autónoma de Nariño, Pasto 520001, Colombia
}

Corresponding Author Email: leandro.lorente@sdas-group.com

https://doi.org/10.18280/ijdne.160113

Received: 24 August 2020

Accepted: 28 January 2021

Keywords:

wind turbines, working temperature, CFD,

heat, bearing, lubricant, simulation

\begin{abstract}
After studies related to the technical state and behavior of the temperatures manifested by the bearings of the generators that make up the Goldwind wind turbines models S50750, installed in the Gibara II Wind Farm (PE). It was identified and validated as a tool that enables early diagnosis of anomalous bearing behaviors, SolidWorks (SW) computer-aided design and engineering software (CAD-CAE) and the Flow Simulation add-on. Since it allows studies based on the computational fluid dynamics (CFD), of the temperatures that are manifested in the lubricant during the different working regimes of the generator. The studies carried out evaluated the environmental conditions of exploitation in Cuba. It works on obtaining and predicting the values of the thermal state using the principles and methods for the calculation of heat transfer, the forecast statistics apply. The research supports its theories and postulates in a sample of 6 installed equipment, from China, for it had a historical database that collects temperature measurements in different working conditions which allowed to establish correlation between theoretical predictions and real behaviors.
\end{abstract}

\section{INTRODUCTION}

Wind energy offers great guarantees in the modern energy sector, the growth trend in installed wind capacity continues to be positive. Thus, companies dedicated to energy distribution invest mainly in projects related to the wind sector [1]. This has made the United States, Denmark, Spain and China the leading manufacturers of wind turbines [2]. It is a mature, reliable technology; with guarantees for manufacturers and investors to reasonably recover costs.

Wind turbine installations in areas where the climate reaches high temperatures and/or high percentages of humidity present the difficulty of getting these wind turbines to work in nominal conditions, not being able to work at maximum capacity. This problem becomes more acute when the wind speed increases, precisely when the conditions for efficient generation exist.

One of the main causes of this problem lies in the limitations of the internal components located in the wind turbine nacelle, such as the gearbox, the generator and the ventilation system. The bearings are known to be one of the main sources of heat. It is the objective of this investigation to describe the influence that the lubrication levels have on the generator bearings, considering the climatic conditions during which the heating in the turbine nacelle is manifested.

There are several techniques for the diagnosis, monitoring and maintenance of bearings in wind turbines. It is proposed that, to guarantee that wind turbines work safely and efficiently, it is necessary that their technical condition meets the requirements established by the technical operation rules. However, it is unavoidable that during operation of the equipment, damage may occur which results in the interruption of its work. This occurs when wear and tear reach its limit values due to breakage, deformation or other impermissible alterations to parts and assemblies. It is therefore necessary to carry out work to eliminate or reduce these faults and thereby restore the momentary loss of the wind turbine's working capacity by carrying out corrective maintenance [3].

Preventive maintenance tasks on the bearings should be aimed at ensuring the ideal operating conditions, this increases the life cycle and prevents overheating. This is achieved by maintaining the established parameters of alignment, rigidity, damping, ventilation and lubrication. This research focuses on determining the relationship between the level of lubrication and the heat generated.

Other researchers propose to perform condition monitoring and apply Wavelet functions that allow to detect incipient failures due to variations in the bearing geometry [4]. But in the case study, temperature alarms are related to lubrication levels and working regimes. Therefore, a correct analysis of the lubricant and an appropriate interpretation of the results can contribute to reduce these interruptions.

Oil analysis is one of the most useful, precise and practical diagnostic techniques used to determine the condition of certain components in a wind turbine [5]. Nowadays, the 
vertiginous development of technologies has led to the foundations of Industry 4.0 reaching unimaginable levels of maintenance. One of the most widespread applications in the study of wind turbines are the so-called digital twins. It is as its name indicates them analysis of behavior or technical processes in equipment by means of simulations that use CAD models to carry out CAE studies. Within the wide field of CAE studies is the CFD, a technique that has its beginnings at the end of the last century, with the application of the Euler equations in two and later in three dimensions and in the middle of the 80 's, where the interest was shifting towards viscous fluids and therefore towards the complete resolution of the Navier-Stokes equation.

CFD-based studies have helped to solve problems associated with fluid dynamics. There have been several professional design software's for the study of fluids that have been programmed, for example, SolidWorks in its latest versions. Where they have enhanced complements like Flow Simulation, "based on the Navier-Stokes equations for studies of laminar and turbulent fluids [6]. The researchers agree with what has been explained in SolidWorks [7], choosing it as a method through which predictive research associated with fluids and heat transfer can be carried out, due to the reliability and possibilities it offers for studies of hydrodynamic behavior [8], determination of thermal gradients [9], airflow modeling [10].

Research by Vera-Tudela and Kühn [11] analyses the prediction of wind turbine fatigue loading, considering the impact of wind farm flow conditions. Other researchers [12] propose a novel approach for determining wind turbine failures by modelling the environmental conditions to which they are exposed. Developing failure modelling based on climatic conditions Similarly [13] they model the effects of environmental conditions on wind turbine failures, showing results of the developed model, which performs satisfactorily in several situations, such as modelling general wind turbine failures, as well as specific component failures.

Further research [14] develops a systematic analysis of the effects of failure mode and criticality of offshore wind turbine systems towards integrated condition-based maintenance strategies. Where they obtain results that can be used to monitor systems focusing on critical analysis and finding optimal operation and maintenance. Rommel et al. [15] propose a load-based maintenance approach to predict the life of wind turbines. They propose a set of parameters that need to be monitored in a wind turbine for the practical implementation of a specific maintenance policy. They also [16] perform a systematic analysis of the effects and failure mode, and critique for offshore wind turbine systems towards integrated condition established maintenance strategies.

\section{MATERIALS AND METHODS}

According to the available database, the records correspond to the simulated ones. It was defined that the temperatures inside the nacelle range from $20.05^{\circ} \mathrm{C}$ to $115.53^{\circ} \mathrm{C}$, with an average value of $67.79^{\circ} \mathrm{C}$, which is above the value established by the manufacturer. The environment inside the nacelle should be around $308 \mathrm{~K}\left(35^{\circ} \mathrm{C}\right)$ since the fan of the oil cooling system turns on at this temperature value and does not turn off until it reaches $303 \mathrm{~K}\left(30^{\circ} \mathrm{C}\right)$, an event that never occurs, that is, the fan is practically working during the entire power generation process. It is also recommended to analyze the heating of the bearings, an important thermal source inside the nacelle.

Arbella et al. [17] with the use of CAD-CAE tools and the fundamentals of thermodynamics developed the models to evaluate the thermal behavior in the nacelle of the Goldwind S50/750 Wind Turbines installed in the Gibara II Wind Farm (Figure 1). These models can be applied in other environmental and working conditions [18]. It is sufficient to adjust input parameters such as temperature, solar radiation, relative humidity, wind speed and direction, which correspond to climatic conditions of the study and simulations evaluated. The aforementioned parameters would be conditioned by topographic position in which the wind sites are built.

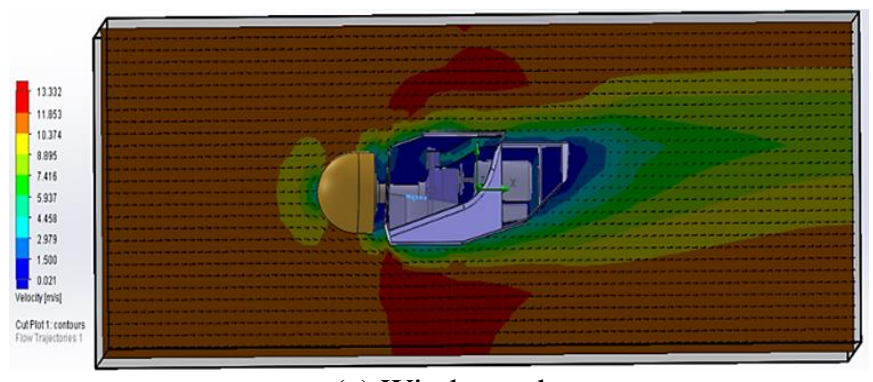

(a) Wind speed

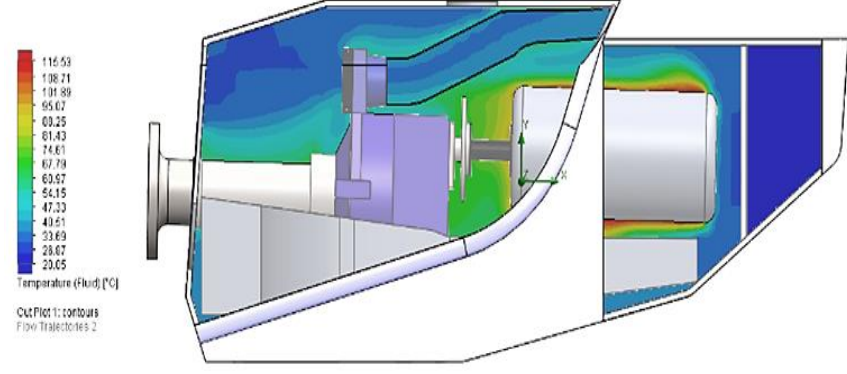

(b) Temperatures

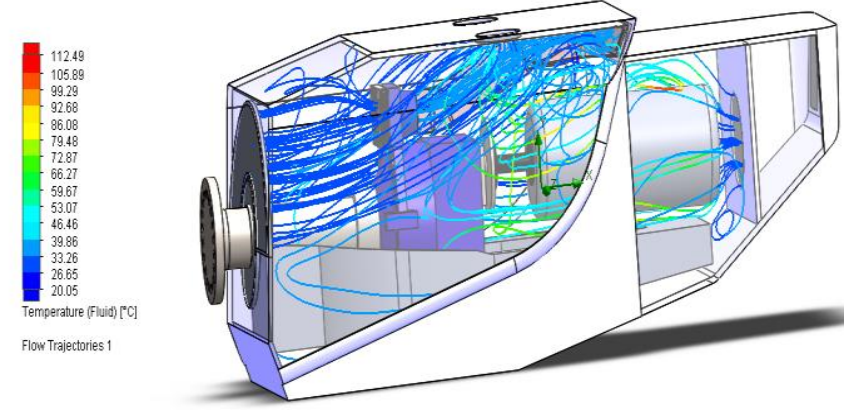

(c) Air and temperature combinations

Figure 1. Behavior inside the nacelle

These Gibara PE wind turbines frequently disconnect when the wind speed increases above $11.5 \mathrm{~m} / \mathrm{s}$, due to high temperatures in their components, mainly the generator winding and its front bearing.

Figure 2 shows the relationship between wind speed and temperatures recorded in the generator winding and bearing, which occupies position 1 . When the wind speed exceeds 11 $\mathrm{m} / \mathrm{s}$, the temperature of these elements increases above the parameters established by the manufacturer. The automatic starts its protection functions against continuous heating of the bearing above the limit set at $90^{\circ} \mathrm{C}$, the 526 alarm is triggered by the PT 100 temperature sensor. These stops take approximately 25 minutes to restore the operation of the wind turbine; precisely now when the conditions are ideal for producing high levels of energy. 
Therefore, Flow Simulation is selected as a tool to simulate the heating process in the bearings. The technical descriptions and operating manuals associated with the Goldwind Wind Turbine model S50/750 [18-21] were consulted. In the investigation, the lubricant Mobil SHC 100 (synthetic grease), manufactured by one of the world leaders in the production of lubricant [22], whose general characteristics are: lithium complex grade NLGI 2, ISOVG 100, synthetic grease recommended for industrial use, with a temperature range from (4.4 to 176.6$){ }^{\circ} \mathrm{C}$. The evaluated bearing is model SKF FY60 VA201. The recording and processing of the SCADA information was done in the Excel software.

For this purpose, 105, 120 ten-minute records of temperatures and variables from 2017 to 2019 were processed and analyzed, like the one shown in Table 1.
Trend of the parameters

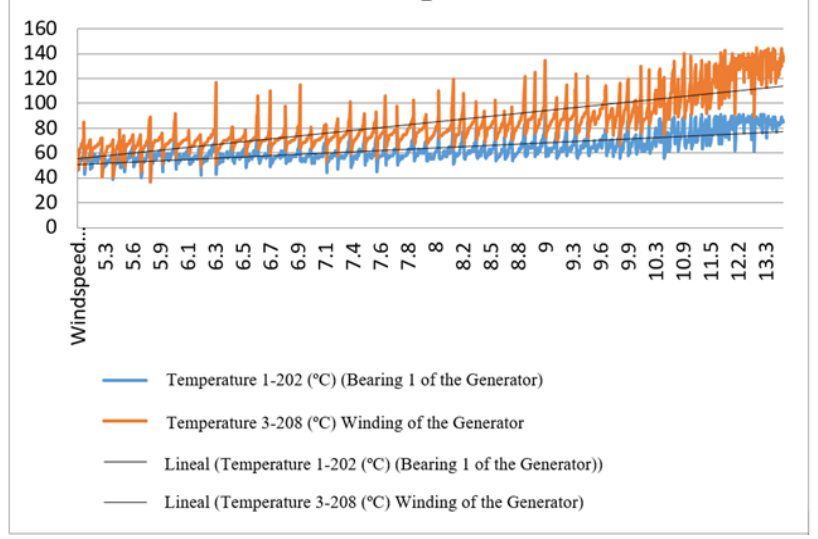

Figure 2. Trend of temperature parameters recorded in the generator

Table 1. Ten-minute temperatures generated by the SCADA system

\begin{tabular}{|c|c|c|c|c|c|c|c|c|}
\hline Date and Hour & $\begin{array}{c}\text { Generation } \\
(\mathbf{k W})\end{array}$ & $\begin{array}{c}\text { Temp } 1 \\
\left({ }^{\circ} \mathrm{C}\right)\end{array}$ & $\begin{array}{c}\text { Temp } 2 \\
\left({ }^{\circ} \mathrm{C}\right)\end{array}$ & $\begin{array}{c}\text { Temp } 3 \\
\left({ }^{\circ} \mathrm{C}\right)\end{array}$ & $\begin{array}{c}\text { Temp } 5 \\
\left({ }^{\circ} \mathrm{C}\right)\end{array}$ & $\begin{array}{c}\text { Temp } 6 \\
\left({ }^{\circ} \mathrm{C}\right)\end{array}$ & $\begin{array}{c}\text { Temp } 7 \\
\left({ }^{\circ} \mathrm{C}\right)\end{array}$ & $\begin{array}{c}\text { Wind Speed } \\
(\mathrm{m} / \mathrm{s})\end{array}$ \\
\hline $6 / 03 / 20187: 10$ & 56 & 49 & 41 & 63 & 52 & 54 & 22 & 5 \\
\hline $6 / 03 / 20187: 00$ & 241 & 48 & 40 & 63 & 52 & 54 & 22 & 8 \\
\hline $6 / 03 / 20186: 50$ & 76 & 48 & 40 & 61 & 52 & 54 & 22 & 5 \\
\hline $6 / 03 / 20186: 40$ & 98 & 52 & 43 & 65 & 53 & 55 & 22 & 6 \\
\hline $6 / 03 / 20186: 30$ & 120 & 49 & 40 & 63 & 52 & 54 & 22 & 6 \\
\hline $6 / 03 / 20186: 20$ & 73 & 48 & 40 & 61 & 52 & 54 & 22 & 5 \\
\hline
\end{tabular}

Temperature 1: Generator bearing 1 temperature.

Temperature 2: Generator bearing 1 temperature.

Temperature 3: Generator winding temperature.

Temperature 5: Gearbox oil temperature.

Temperature 6: Bearing temperature of the gearbox.

Temperature 7: Ambient temperature.

With the data shown in the table above and a set of measurements made later, it is determined that the system protects, but is not able to predict. In this regard, Quispe Mendoza [23] considers the limitations of SCADA in statistical studies for condition monitoring. Given that the SCADA systems in the technology studied, as their name suggests, control, acquire and alert regarding instantaneous behavior of the equipment, they do not generate technical predictions. A clear example is the failures resulting from the correlation between critical wind speed, solar radiation, time of day and relative humidity. The aforementioned independent variables influence the good condition of the bearings, since the resulting temperatures inside the nacelle, gearbox and generator are the result of climatic combinations in the case of asynchronous wind turbines. Practice has shown that wind speeds above $11 \mathrm{~m} / \mathrm{s}$ generate failures closely related to the automatic high temperature protection of the generator bearings. Taking into account the previous criterion, the relationship between wind speed and bearing rotation frequency and the surrounding temperatures was determined, which would be transferred by conduction to the lubricant studied. For this purpose, the characteristics provided by Gonzalez et al. [24] were considered. The results obtained in the investigation were validated by a set of tests and measurements that were carried out after the simulations were completed. This made it possible to make predictions, by means of numerical simulation of the lubricant and air flow, which predict and optimize values of operational temperatures in the bearings studied. Obtaining graphic patterns based on
CFD that show temperature behavior in the lubricant of the bearings under study.

\section{RESULTS AND DISCUSSION}

After modelling and simulating the SKF bearing studied (see Figures 3 and 4) that composes the electric generator of the wind turbine, working in the different lubrication conditions under the same level of revolutions per minute and levels of wear, the different temperature behaviors in the lubricant and the solid were identified, as shown below. Levels of completions with lubricant in bearings were studied for $10 \%$; $20 \% ; 30 \% ; 40 \% ; 80 \%$ and $90 \%$ of the volume of free space to be lubricated. The results show how flow simulation can help the engineer predict and optimize heat and eloquent flows, solving engineering problems.

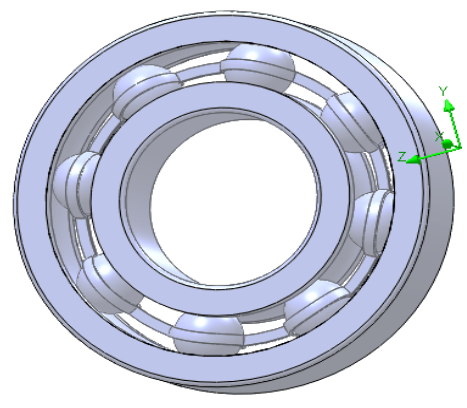

Figure 3. SKF bearing model studied 


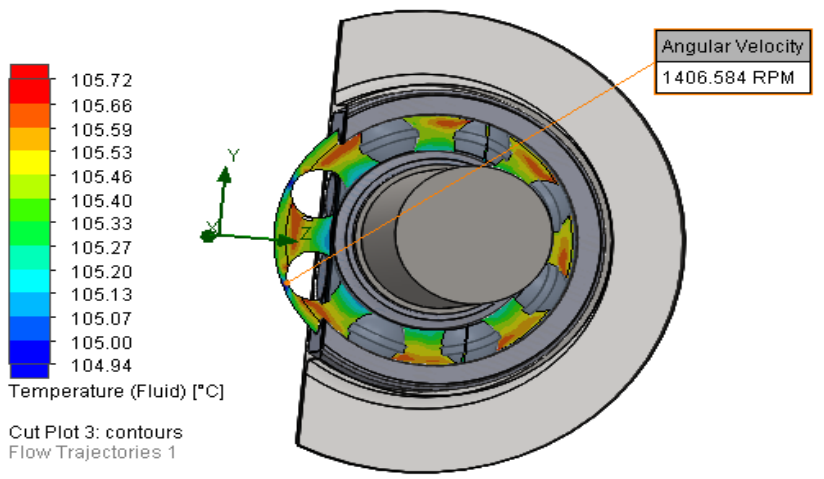

Figure 4. CFD-based thermal studies
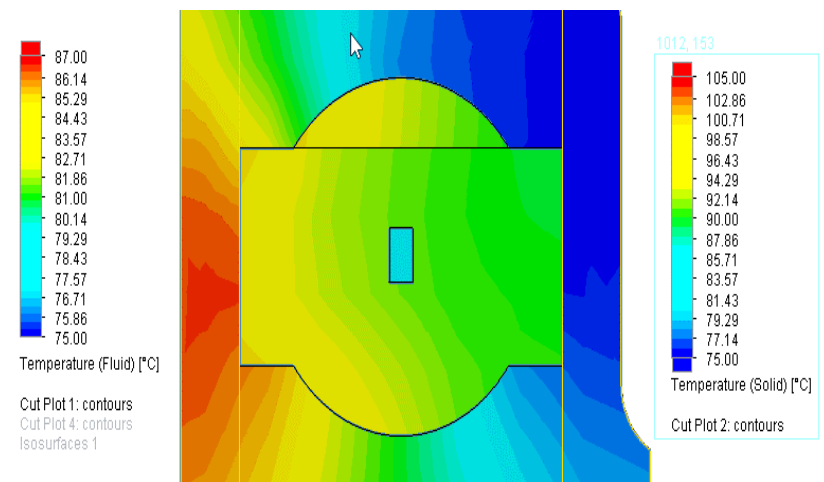

(a) Completion with $10 \%$ lubrican

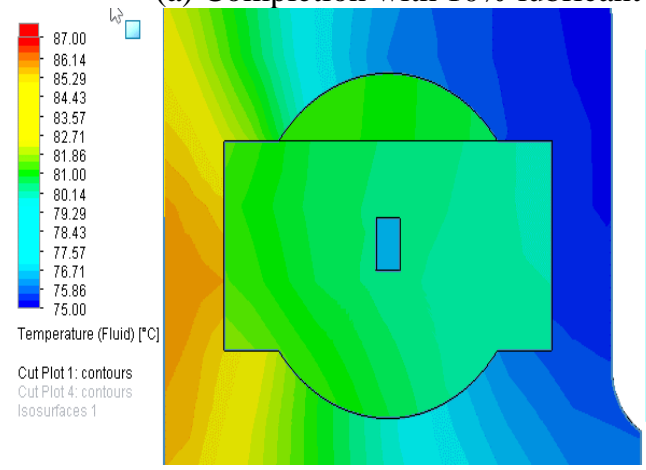

(c) Completion with $80 \%$ lubricant
In the Figure 5, the highest temperatures in the solid are shown in simulations a and $\mathrm{d}$, which have been simulated with $10 \%$ and $90 \%$ lubrication completion, respectively. In the cases of studies b and c, with $20 \%$ and $80 \%$ lubrication, the trend is towards lower temperatures. Therefore, it is graphically evident that both over- and under-lubrication of bearings can impair the working conditions because of high temperatures.

In the same way, the simulation is carried out for other values of lubricant completeness and the behavior of the studied phenomenon can be described. A mathematical model is obtained to predict the working temperature values in the number one bearing of the electric generator that integrates the WT Goldwind operated in Cuba under the conditions analyzed (Figure 6).
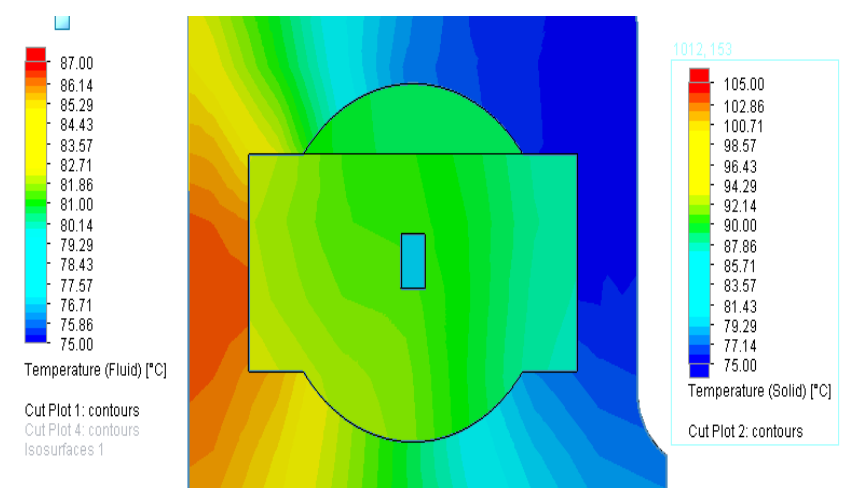

(b) Completion with $20 \%$ lubricant
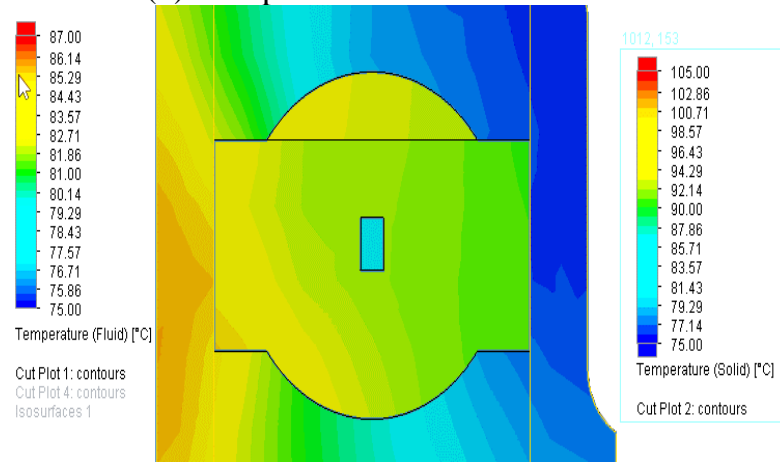

(d) Completion with $90 \%$ lubricant

Figure 5. Simulated temperature behaviour of the solid and the lubricant at different percentages of completion with lubricant of the free air volume inside the bearing

Generator bearing number 1 temperature in Goldwind S 50/750 wind turbines vs. \% clearance volume inside the lubricated bearing, for wind speeds above $11 \mathrm{~m} / \mathrm{s}$

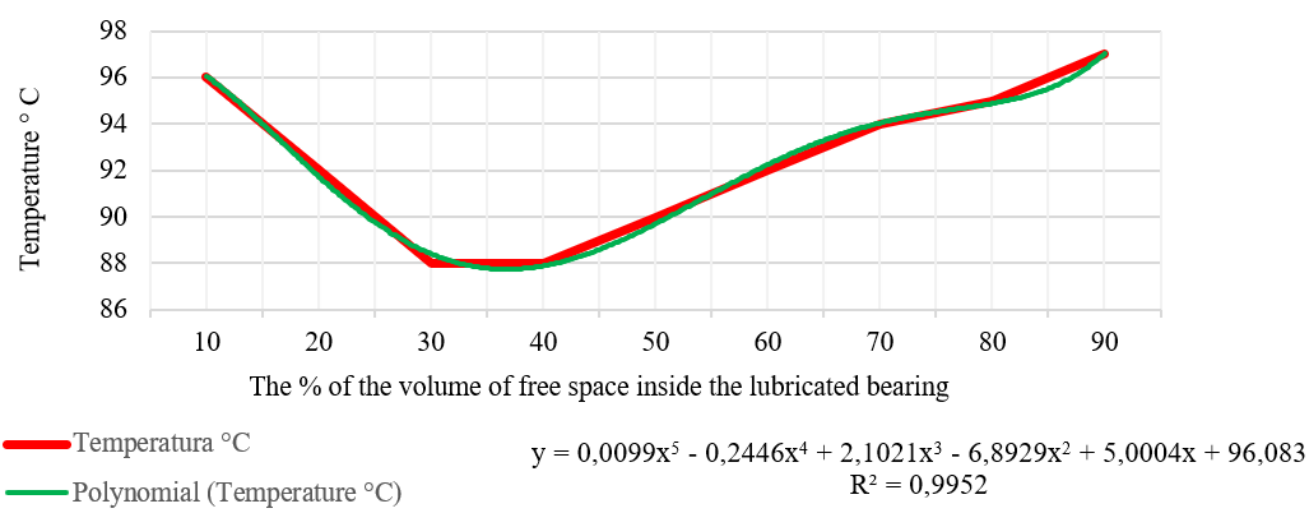

Figure 6. Model to predict working temperature values at bearing number 1 


$$
\begin{gathered}
Y=0.0099 x^{5}-0.2446 x^{4}+2.1021 x^{3}-6.8929 x^{2}+5.0004 x \\
+96.083
\end{gathered}
$$

Fifth order polynomial equation that allows correlating temperature in the SKF bearing fluid studied (y), as a function of the lubrication percentage $(\mathrm{x})$, for a working angular speed of $1407 \mathrm{~min}^{-1}(\mathrm{rpm})$, resulting from the transmission ratio caused in the wind turbine by the wind speed equal to $11 \mathrm{~m} / \mathrm{s}$, under the climatic conditions of exploitation of the PE Gibara II located in Cuba. The surface roughness levels established for bearings by SKF manufacturers were taken as a reference for simulations.

It was determined that the optimum level of lubrication in the work regime studied is between $30 \%$ and $40 \%$, which can be seen in the simulations in Figure 7.

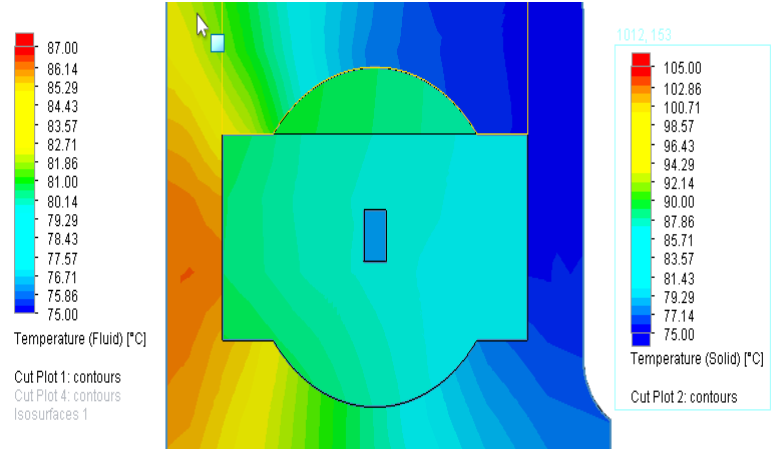

(a) Completion with $30 \%$ lubricant

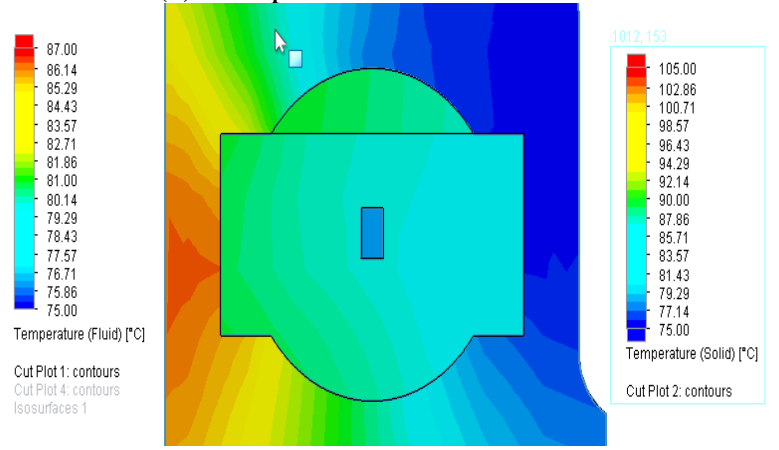

(b) Completion with $40 \%$ lubricant

Figure 7. Simulated temperature behaviour in the solid and the lubricant, at $30 \%$ and $40 \%$ completion with lubricant of the free air volume inside the bearing

The use of CFD simulation made it possible to analyze a tribological problem associated with heat transfer, which is very common in bearings, visualizing how, when lubrication levels increase by more than fifty percent, temperatures rise, constituting an important source of heat inside the nacelle, causing protection alarms in wind turbines.

In this work, the researchers deepen the study and develop the evaluation of the behavior of temperatures in bearings, aided by CAD-CAE tools due to the importance for the country to tropicalize operation and maintenance parameters in wind turbines. By means of an analysis of the related literature through the structuring of search chains that relate the subject under study, it was possible to identify the absence of research where condition monitoring based on SCADA systems is combined with design and numerical simulation to simulate and evaluate working temperatures in bearings, enhancing an adequate lubrication to the operating conditions of tropical countries with similar characteristics to those of Cuba.

\section{CONCLUSIONS}

The use of the CFD allowed the evaluation of the working temperature of the bearing, in correspondence with the level of lubricant, defining that its optimal value is between $40-50 \%$ of completion with lubricant of the volume of free air inside it. This preventive action allowed to decrease the working temperature in the bearing number 1 of the generator, important source of heat inside the nacelle of the Goldwind S50/750 wind turbines of Gibara PE.

The proposed method can be applied to the rest of the bearings of these turbines to improve working conditions and extend their life cycle. Similar analyses can be carried out on equipment and machine bearings.

\section{REFERENCES}

[1] Van Branteghem, P. (2015). Validación de modelos CFD de recurso eólico. Trabajo de Fin de Master, Universidad Complutense de Madrid, Spain.

[2] Figueredo, C.M. (2015). Estado actual y perspectivas de la energía eólica. In: VIII Conferencia Internacional de Energía Renovable, Ahorro de Energía y Educación Energética, Palacio de Convenciones de La Habana, Cuba.

[3] Pérez, P.L. (2017). Estudio causal de la rotura del cable de retención de puntas de palas de los aerogeneradores modelo S 50 - 750 del Parque Eólico Gibara 2. Tesis de Ingeniero Mecánico Universidad de Holguín, Cuba.

[4] Chen, J., Pan, J., Li, Z., Zi, Y., Chen, X. (2016). Generator bearing fault diagnosis for wind turbine via empirical wavelet transform using measured vibration signals. Renewable Energy, 89: 80-92. https://doi.org/10.1016/j.renene.2015.12.010

[5] López, M. (2015). Metodología para sistemas inteligentes de detección de mal funcionamiento en equipos. Aplicación a los aerogeneradores. Escuela Técnica Superior de Ingeniería Industrial, Universidad de La Rioja.

[6] SolidWorks. (2016). Technical Reference SolidWorks Flow Simulation.

[7] SolidWorks (2016). Tutorials SolidWorks Flow Simulation 2016.

[8] Díaz, S. (2018). Estimación del coeficiente de transmisión y análisis hidrodinámico para arrecifes tipo REEF-CELLS para condiciones marinas del Caribe colombiano mediante modelación CFD. Universidad del Norte.

[9] Espinal-Montes, V., López-Cruz, I.L., Rojano-Aguilar, A., Romantchik-Kriuchova, E., Ramírez-Arias, A. (2015). Determinación de los gradientes térmicos nocturnos en un invernadero usando dinámica de fluidos computacional. Agrociencia, 49: 233-247.

[10] Herrera-Prat, M., Figal-Costales, A., Cuevas-Milán, H., Martins-Teixeira, M. (2018). Modelación de la corriente de aire en el plano vertical del pulverizador agrícola Hatsuta. Revista Ciencias Técnicas Agropecuarias, 27(2): $1-8$.

[11] Vera-Tudela, L., Kühn, M. (2017). Analysing wind turbine fatigue load prediction: The impact of wind farm flow conditions. Renewable Energy, 107: 352-360. https://doi.org/10.1016/j.renene.2017.01.065

[12] Reder, M., Melero, J.J. (2017). Modelling wind turbine 
failures based on weather conditions. Journal of Physics: Conference $\quad$ Series, $\quad 926(1)$ : 012012. https://doi.org/10.1088/1742-6596/926/1/012012

[13] Reder, M., Melero, J.J. (2018). Modelling the effects of environmental conditions on wind turbine failures. Wind Energy, 21(10): 876-891. https://doi.org/10.1002/we.2201

[14] Scheu, M.N., Tremps, L., Smolka, U., Kolios, A., Brennan, F. (2019). A systematic failure mode effects and criticality analysis for offshore wind turbine systems towards integrated condition based maintenance strategies. Ocean Engineering, 176: 118-133. https://doi.org/10.1016/j.oceaneng.2019.02.048

[15] Rommel, D.P., Di Maio, D., Tinga, T. (2020). Calculating wind turbine component loads for improved life prediction. Renewable Energy, 146: 223-241. https://doi.org/ 10.1016/j.renene.2019.06.131

[16] Maldonado-Correa, J., Martín-Martínez, S., Artigao, E., Gómez-Lázaro, E. (2020). Using SCADA data for wind turbine condition monitoring: A systematic literature review. Energies, 13(12): en13123132. https://doi.org/10.3390/en13123132.

[17] Feliciano, Y.A., Trinchet, C.A., Meléndez, E., LorenteLeyva, L.L., Peluffo-Ordóñez, D.H. (2020). Analysis of the thermal behavior in the Goldwind S50/750 Wind Turbines installed in the Wind Farm Gibara II using CAD-CAE Tools. International Journal of Mechanical and Production Engineering Research and Development, 10(2): IJMPERDAPR202032. https://doi.org/10.24247/ijmperdapr202032

[18] Feliciano, Y.A., Trinchet, C.A., Vargas, J.A., Lorente-
Leyva, L.L. (2020). Influences of the temperature variations in the gondola of the goldwing S50/750 wind. International Journal on Advanced Science, Engineering and Information Technology, 10(6): 2634-2639. http://dx.doi.org/10.18517/ijaseit.10.6.11340.

[19] AENOR. (2006). Aerogeneradores Parte 1: Requisitos de diseño (IEC 61400-1:2005), ed: Editada e impresa por AENOR Deposito legal: M 28830:2006.

[20] Science\&Technology. (2007). Goldwind S50/750 Wind Turbine Technical parameters and Product description $(60 \mathrm{~Hz})$. In seccion de titulo vol. $\mathrm{Q} / \mathrm{JF}$ 2CP50/750.2-2007, ed. China: LTD Industry Standard.

[21] Goldwind Science \& Technology Co. Ltd. (2008). Goldwind S50/750 Wind Turbine Generator System Operation and Maintenance Manual for Cuba Project (50m High 3-section Tower in IEC Wind Class IIA, $60 \mathrm{~Hz})$.

[22] Enterprise Standard of Goldwind Science \& Technology CO. (2008). Goldwind $750 \mathrm{~kW}$ series Wind Turbine Electric Drawings. Ed: Goldwind Science \& Technology CO., LTD.

[23] Quispe Mendoza, A. (2017). Implementación del análisis de lubricante como herramienta de mejora en el monitoreo de condición del aceite en unidades hidráulicas y cajas reductoras en la empresa OPP FILM para el año 2017.

[24] Gonzalez, E., Tautz-Weinert, J., Melero, J.J., Watson, S.J. (2018). Statistical Evaluation of SCADA data for Wind Turbine Condition Monitoring and Farm Assessment. Journal of Physics: Conference Series, 1037(3): 032038. https://doi.org/10.1088/1742-6596/1037/3/032038 